\title{
Культурологія
}

UDC 378.4(477-25)КНУКіМ:005.342

\author{
Poplavskyi Mykhailo. \\ Doctor of Pedagogical Sciences, Professor, \\ Kyiv National University of Culture and Arts \\ ORCID 0000-0002-8234-8064 \\ Pomm20180326@gmail.com
}

\section{INNOVATIONS IN ARTS AND CULTURAL EDUCATION: EXPERIENCE OF THE KYIV NATIONAL UNIVERSITY OF CULTURE AND ARTS}

The features of arts and cultural education in the context of general trends in social development are studied. The issues of professional training of arts and culture-related experts are relevant not only for Ukraine but also for other European countries, which experience attracts the attention of researchers and experts who are trying to apply it in higher school. The purpose of the article is to reveal the experience of MA in education in arts and culture setting, combining traditional and up-to-date programs of study. There is research in the methodology of historical and theoretical analysis and modeling approaches. With all the progressiveness of educational technologies offered by modern pedagogical science, one should not abandon the historical experience in this field. With all the progressiveness and relevance of training technologies offered by modern educational science, one should not refuse from historical experience in this area. The Kyiv National University of Culture and Arts successfully test various educational models, in particular, retro-archaic and creative. The retro-archaic model combines the fringe locality of teaching (teacher) and modern information technologies, thanks to which the recipient does not just receive information, but also "school" oneself. This model is elite, exclusive and exotic, despite its retro-archaic backgrounds. The creative model prevents from providing knowledge as impersonal information. It is especially relevant in the arts and cultural teaching of students that based on the direct share of experience (skill) and the value of interpersonal communication. The university uses both models in the preparation of creative projects by students as one of the forms of graduate qualification work for the degree of master. The scientific novelty of the article consists in revealing the experience of master's art design that meets the key features of modern cultural and creative activity - cultural potential, social-cultural demand, theoretical and framework rationale, aesthetic-art and ethical-educational focus, commercial and recreational-entertaining "performance". Conclusions. We call such a setting for the formation of project competencies a "crossover point" (in English - "intersection point", "intersection") as the principle of preparation and presentation of a creative project. There are test laboratories that work as workshops for teaching arts and culture-related students (audio-visual arts and production, design, choreography, musical art, and stage art). It is developed and tested an "ideal" model for the training of masters in the process of creative and design activity. MA`s creative project contains both research and experimental backgrounds combining design modeling and scientific activity. Conclusions. We believe that it is necessary to develop a creative education research program, a non-aggressive and non-constructive approach based on cultural and historical reenactment, design-model analysis and creative thinking. It will allow us to form not only a creative personality, but also a creative community, and creative society.

Key words: higher arts and cultural education, MA`s creative project, educational model.

Поплавський Михайло Михайлович, доктор педагогічних наук,професор, Київський національний університет культури і мистецтв

Інновації в культурно-мистецькій освіті: досвід Київського національного університету культури і мистецтв

Мета статті - охарактеризувати процес підготовки магістрів творчих спеціальностей шляхом поєднання традиційних і новітніх моделей освіти. Методологію дослідження становлять методи історико-теоретичного аналізу й моделювання. За всієі прогресивності освітніх технологій, які пропонує сучасна педагогічна наука, не варто відмовлятись і від історичного досвіду у цій сфері. У КНУКіМ успішно апробуються різні освітні моделі, зокрема ретроархаїзуюча і креативна. Ретроархаїзуюча поєднує радикальну локальність навчання (викладач) і сучасні інформаційні технології, завдяки яким реципієнт не просто здобуває інформацію, а «виховує» самого себе. Ця модель елітарна, ексклюзивна й екзотична, незважаючи на її ретроархаїчні засади. Креативна модель не припускає засвоєння знань як знеособленої інформації. Вона особливо актуальна в культурно-мистецькій підготовці студентів, заснованій на безпосередньому переданні досвіду (майстерності) і міжособистісному спілкуванні. В університеті застосовуються обидві моделі у підготовці студентами творчих проектів як однієї із форм випускової кваліфікаційної роботи на здобуття освітнього ступеня «магістр». Наукова новизна статті - розкрито досвід магістерського мистецького проектування відповідно до ключових ознак сучасної культурно-креативної діяльності - культуротворчий потенціал, соціокультурний запит, теоретико-концептуальне обґрунтування, естетико-художню й етико-виховну спрямованість, комерційну й рекреаційнорозважальну “технологічність". Висновки. Таку настанову на формування проектних компетенцій ми називаємо "crossover point" (від англ. - "точка переходу', “перетин”) як принцип підготовки і представлення мистецького проекту. Працюють експериментальні лабораторії за принципом творчих майстерень з підготовки фахівців культурно-мистецьких галузей (аудіовізуальне мистецтво і виробництво, дизайн, хореографрія, музичне мистецтво, сценічне мистецтво). Магістерський творчий проект містить науково-дослідну й експериментальну складові, поєднуючи проектне моделювання і наукову діяльність. Висновки: назріла потреба розробити науково-дослідну програму з креативної педагогіки, методику неагресивного, неінструктивного підходу на основі культурно-історичної реконструкції, проектно-модельного аналізу і творчого мислення. Це надасть змогу формувати не тільки креативну особистість, а й креативний клас, креативне суспільство.

Ключові слова: вища культурно-мистецька освіта, магістерський творчий проект, освітня модель.

Поплавский Михаил Михайлович, доктор педагогических наук, профрессор, Киевский национальный университет культуры и искусств

Инновации в культурно-художественном образовании: опыт Киевского национального университета культуры и искусств

Цель статьи - охарактеризовать процесс подготовки магистров творческих специальностей, сочетая традиционные и новейшие модели образования. Методологию исследования составляют методы историко-теоретического анализа и моделирования. При всей прогрессивности и актуальности педагогических технологий, предлагаемых современной педагогической наукой, не стоит отказываться от исторического опыта в этой сфрере. В КНУКиИ апробируются различные образовательные модели, в частности ретроархаизующая и креативная. Ретроархаизующая сочетает радикальную локальность обучения (пре-

(C) Poplavskyi M., 2019 
подаватель) и современные информационные технологии, благодаря которым реципиент не просто усваивает информацию, а «воспитывает» самого себя. Это модель элитарная, эксклюзивная и экзотическая. Креативная модель не предполагает усвоения знаний как обезличенной информации. Она особенно актуальна в культурно-художественной подготовке, в основе которой - непосредственная передача опыта (мастерства) и межличностное общение. Применяются обе модели в подготовке студентами творческих проектов как одной из форм выпускающей квалификационной работы на соискание образовательного степени «магистр». Научная новизна статьи состоит в раскрытии опыта магистерского художественного проектирования, соответствующего ключевым признакам современной культурно-креативной деятельности - культуротворческий потенциал, социокультурный запрос, теоретико-концептуальное обоснование, эстетико-художественная и этико-воспитательная направленность, коммерческая и рекреационно-развлекательная «технологичность». Выводы. Такую установку на фрормирование проектных компетенций мы называем «crossover point» (от англ. - «точка пересечения», «пересечение») как принцип подготовки и представления творческого проекта. Работают экспериментальные лаборатории творческой реализации личности по принципу творческих мастерских, готовящих специалистов культурно-художественной сферы (аудиовизуальное искусство и производство, дизайн, хореография, музыкальное искусство, сценическое искусство). Магистерский творческий проект содержит научноисследовательскую и экспериментальную составляющие, сочетая проектное моделирование и научную деятельность. Выводы: необходимо создать научно-исследовательскую программу по креативной педагогике, методику неагрессивного, неинструктивного подхода на основе культурно-исторической реконструкции, проектно-модельного анализа и творческого мышления. Это позволит фрормировать не только креативную личность, но и креативный класс, креативное общество. ная модель.

Ключевые слова: высшее культурно-художественное образование, магистерская творческий проект, образователь-

Arts and cultural education in Ukraine is not only influenced by the general trends occurring in the higher education system but also is filled with innovative searches due to the peculiarities of its content, purpose and objectives. Problems of its improvement and modernization attract the attention of modern researchers, in particular in cultural studies (Yu. Afanasyev, V. Bitaev, V. Mazepa, V. Lichkovakh, L. Levchuk`s), pedagogy (I. Ziazun, H. Padalka, O. Rudnitskaya, V. Orlov, O. Oleksyuk, O. Shcholokova`s), study of art (S. Volkov, I. Lyashenko, O. Mayorova, O. Malozyomova, S. Nikulenko, O. Ovcharuk, L. Sokolyuk, L. Savitska, R. Shmagal, V. Shulgina, K. Shamayeva`s).

In an increasingly integration process environment, the top issue is theoretical and methodological justification of the today's expert training, taking into account the prospects of development of continuous professional education. The research of these issues is important to focus on the justification of professional education as a science of general and specific laws, patterns, principles, features, and conditions of development of professional education and teaching, professional training and personality formation of the rising skilled specialist $[8,60]$.

Today, these issues are urgent not only for Ukraine but also for other European countries which experience attracts the attention not only of researchers but also of practitioners who tend to apply it in higher education. However, according to O. Zhurakovsky, a researcher at the University of Bristol (UK), the mechanical transfer or adoption of pedagogical technologies from Western educational systems only complicates the situation, as happened with the implementation of the Bologna system into Ukrainian higher education institutions. "Modern society believes that more education - no matter which - the better. The percentage of the public that holds a diploma is constantly increasing. And percentage of doctoral degrees is increasing also. As the proportion of geniuses does not increase, we have education inflation. This is largely responsible for the fact that in the 21st century, a holder of bachelor's degree, or even a doctor of science, are ordinary workers, anything but intellectual elite. The availability of a diploma no longer indicates your outstanding ability or status $[4,28]$.

Tending to cultivate a harmoniously developed creative personality, to form one's discovery learning, research abilities, it is essential to recall that the historical experience proves that the most effective, especially in the training of the arts and cultural-related experts, is the face-to-face communication of the teacher with a student or with a small number of students. Under such conditions, they each bring in contact to develop their natural abilities, facilitating the syncretic identification and personification of information: the recipient both performs thought and learns to think independently and original at the same time.

It's of current interest, when pretty much every public values including morality, aesthetics, science, education have undergone transformations. Indeed, the desire to "upgrade" and borrow the Western models of socio-cultural development has turned to total McDonaldization right before our very eyes, the distribution of poor-quality sophisticated products of "fast consumption" and not only concerning food but the culture in general. Eerily, there is the continuous knowledge inflation, unlearning that had been cultivated for centuries and defined our cultural identity, although a number of universities, that are equal to "national", the number of graduates is only growing every year. Indeed, the diploma of higher education or degree does not indicate any special ability, thoroughness of knowledge or the academic perspective of the person.

On the one hand, oftentimes the scope of new knowledge is going up in today's world, it is impossible to cover and acquire it even with the help of modern information technologies, and again, new discipline, new professions emerge, in which acquired knowledge and skills get outdated fast, but there is a need for another new one. Experts increasingly insist on the fact that now the main task of universities is to teach their graduates to learn, and they, having these skills, will be able to react accordingly to the demand of time and labor market. In addition, for some professions relevant is a thorough theoretical training, for others, there are practical skills, and there are those who require the close coordination of both. So with all progressiveness and relevance of modern educational technologies, it is not necessary to give up the historical experience gained in this field. 
The purpose of the article is to reveal the experience of arts and cultural-related MA training by combining traditional and up-to-date educational models in the learning process.

In the modern humanitarian University, it is possible to apply different educational models, in particular, retro-archaic and creative. Retro-archaic model combines fringe localism (when a teacher is a tutor, who is well-paid) and universalism of modern information technologies (thanks to the teacher mass media means of education becomes such "tutor", as it only represents the information as a teacher-syncretist and by mimesis, identification teaches the recipient not only to use information and "school" oneself). Today the premium schools are spreading for the "gifted" parents who are able to apply the experience of the noble education. This model is elite, exclusive and exotic, in spite of its retro-archaic background. The universalization of the tutor work in the field of contemporary higher education by means of mass-media technologies is a heuristic and efficient principle, which the leading universities of the world have held for a long time. Tutors programs combine archaic teaching and new scientific approaches, which put emphasis on the adaptability of creating a syncretic subject of study. Further, a measure of elitism will be determined only by the degree of authenticity (humanity) of the tutor, which in this technological model of communication and learning can be easily replaced by artificial intelligence in androids Sofia or Meany (depending on factory settings). This comic (yet?) image of the teacher of tomorrow allows you to identify the valuable core of university education, if we remove technical resource with the automated system monitoring abilities and knowledge of the student, computer modeling of individual educational objectives, and educational management.

Competing creative educational model has become widespread due to the inability of accurate and natural methods to solve the problems of preparing people to the real life of the present and the challenges of the future. In the retro-archaic model, the focus on professionalism, tutoring, and technology creates the illusion that everything can be learned from a computer monitor. In fact, human-like is the only one effective counter-strategy to provide knowledge as impersonal information. The creative educational model is especially relevant in the field of arts and cultural training of students, which is not threatened by robotization and automation, as there is a direct transfer of experience (skills) and value of interpersonal communication within the learning process.

Without favouring either of these models, we apply both at Kyiv National University of Culture and Arts (KNUC\&A), testing each of them in the process of preparing and implementing it creative projects by students as a form of graduate qualification work for a master's degree. The fact is that the MA program can be completed with both scientific work and creative project, which is especially relevant for graduates of arts and cultural-related specialties and specializations.

There is a brief account of the history of the MA introduction at a European university, about its transformations in the educational systems of different countries. Genealogically linked to the culture of the European Middle Ages, the concept of "Master" had several connotations. The master was called a master, a teacher (from Latin - magister), and at a medieval university it was a degree in the scientific hierarchy. This term was introduced into cultural use through the introduction of a fundamentally new cognitive paradigm the production of new knowledge (as opposed to religious instruction to interpret the world as revelation). Accordingly, the university masters guild shared the "confidants" by rank to the creation of this knowledge.

In Ukraine, the master's degree is experiencing a "rebirth". The two-tier model of scientific degrees (Candidate of sciences and Doctor of Science) has been valid as of 1934; since 1999 there has been a master's degree, introduced as a result of the signing of the Bologna Convention by Ukraine. Twenty years of experience in the application of this level proves the need not only to produce appropriate standards, but, based on tradition, to harmonize new educational units with already acquired levels - specialist and Candidate of Sciences. Such master's degree agility in the system of training intended specialists of arts and cultural organizations and related sectors is a positive potential as a strategic tool: institutional instability initiates changes, provides an opportunity to respond quickly to cultural "sensation". This process must permanently update the content and principles of the master's education in the realities of the present. Moreover, university education always reflects public expectations and hopes for what Lina Kostenko called a "humanitarian aura" - a powerful emanating complex of sciences that "covering all spheres of public life, including education, literature, and the arts - in their integument involvement in world culture and, of course, in its unique national version" [5, 3].

The purpose of the master's art project is to identify the student's acquired knowledge, skills acquired to practical needs, student's willingness to solve professional tasks in the arts and cultural aspects like artistic, scientific, organizational, and etc. That educational management, as well as the corresponding content of the disciplines, consistently form the matrix of modelling of creative projects, general requirements to them. It must be completed works of the chosen specialization and type of art, synthetic in nature and essence, since it combines several key features of contemporary cultural and creative activity - cultural potential, sociocultural demand, theoretical and conceptual rationale, aesthetics and ethic-oriented educational focus, commercial and recreational-entertainment "performance" as necessary factors of the modern creative economy. This is the "crossover point"1 we refer to as the direction for the implementation of project competencies. This is the principle of preparation and presentation of an art project as a synthesis of diverse and diversified types of creative and artistic activity. The line of "crossover point" approach development requires a master's ability to "fit" project activity into the "body" of culture as a mechanism of bifurcation and synthesis 
of experimental and initiated actions, initiated by arts-related specialists, who have united for a certain time in a certain cultural location to solve the creatively different arts tasks. That is, an art project is a sequence of conceptually combined components: planning, creation and realization of a synthetic artistic product. After all, these are universal competencies for which there is a strong demand in the modern economy, politics, arts and cultural sector. The question is: How can creativity, capacity for artistic unpredictability be formed in future professionals by working for, let's face it, often outdated educational standards, curricula and programs? How to prepare young people to create inventive socio-cultural projects?

KNUC\&A`s teaching staff has gained considerable experience along the way. The university has been experimenting for several years, conventionally called the of creative personality fulfilment laboratory, working on the principle of creative workshops for the training of specialists in arts and cultural-related sectors (audio-visual arts and production, design, choreography, musical art, performing arts). Introducing this innovative work in arts and cultural education, we have developed an "ideal" model for preparing masters through creative project work. Specialists in the relevant field, who combine teaching and research, are constantly focused on their professional growth and improvement. As carriers and producers of humanistic values, they perceive art, philosophy, science as components of a universal type of creativity. The universal paradigm of the Renaissance creator is taken as a background. It is important to bear in mind that Donatello was friends with Alberti, Michelangelo and Poliziano, and it helped on the artist establishment, the master of the universal type, who needed to clarify the difference between the sculptor and stonecutter (as maestro Granacci, the first teacher of Michelangelo who tried to explain the meaning of the profession of artist to the future father of the Pieta and St. Peter's Basilica) [1, 43]. This is an attribution of general skills that can be conditionally interpreted as "liberal arts" (like the Renaissance idea of a bright creative personality).

This guideline at KNUC\&A is rethought and updated in line with contemporary socio-cultural needs. That is, a culture model, perfect for Europe once, can work today, but not as a perfect-fitting (genius, creative absolute), but as a model of the "artist of our time". It stands to reason that every outstanding art event that takes place in Ukraine is connected with a standout that constantly extends the boundaries of the usual, reasonable, allowable, expected in culture: Bohdan Beniuk, Ostap Stupka, Konstantyn Hrubich, Volodymyr Moiseyenko, Volodymyr Horianskyi, Radu Poklitaru, Anatoliy Matviychuk, Hrygorii Chapkis and others. All of them achieved many in their professions and now teach at our University, actively forming project platforms, initiating creative communication via festivals, forums, competition programs, in the media space, creating art workshops in arts and cultural education. In addition to their artistic creativity, they manage to "happen" in unpredictable situations. It is a modern-day version of the renaissance of creativity, is not it? It is essential for the modern personality, is not it? In the era of technological discoveries, the production of creativity is not just the creation of a new (artificial intelligence is capable of it), but its unexpectedness and unpredictability of ways of realization. These are the basic attributes of creativity that can be practically tested, studying for MA programs, preparing creative and art projects as qualification arts and cultural-related works.

The master's art project contains two components - research (analytical and theoretical) and experimental (practical). Appropriate theoretical justification requires the author to conceptualize the idea, theme and content of his art project, to identify the potential target audience, the consumer, to understand the most difficult moments of its preparation and organization. The practical part is the independent work on the creation of an art project (concert program, theatre performance, television program, film, design project, portfolio based on completed practical works) as a completed work of art in the chosen specialization and type of art. That is, at each stage of preparation of the art project you have to combine design modelling and scientific actions. In the creative workshop teacher forms, harmonizes and reveals the ability of the student due to the project activity, through a combination of creative, artistic, theatrical and expressive approach to rational justification, self-consciousness and philosophical reflection, and worldview. Any modern art project is always a dialogue between the actors, managers, media content, recipients and researchers. An independent and original project is not just to show knowledge and professional skills, it requires the degree of openness to new ideas, the ability to model possible options and features of the "material". The quality of the master's art project is determined, as a rule, by three criteria - artistic, technological and utilitarian.

Art event is designed and embodied by different social and cultural-related specialists. Accordingly, the authors of the project are those who are able deliberately, step by step to create conditions for cooperation and co-creation of all the event participants, subjecting the same ideas and goals (artistic, economic, technical, educational, catharsis, ideological, etc.). The most important task of arts and cultural events requires adherence to these high values to exclude imitation of creativity, the substitution of creative activity with the banal pursuit of competitive advantage, "successfulness" without success. Mechanisms of such substitution were analysed by J.Huizinga in "Homo Ludens", promoting imitation ("false" game, a "pseudogame") in opposition to game as culture creative beginning [3]. At first sight, a subtle difference between creativity and imitation creativity (especially in the realities of the present day) is provided when a person is in a situation of choice, crisis, uncertainty, or there is a lack of universal "rules" of the game.

The epistemological ambivalence and moral relativism are the perfect environment to identify creative abilities of creative personality. In the process of artistic activities there is a kind of "meta I" that is reflecting in different planes - sensitive, the rational, the intuitive and etc. The subject of study, as known as the designer of "I" integrity that synthetically and emotionally experienced as "gift of life" as "a miracle", "revela- 
tion", performs a creative act, fully feeling that he is a creator. Almost existential strains in the process of personal choice, creative experience of creative workshops become the driving mechanism of learning and selfimprovement. This aspect highlights the socio-cultural value of the project activity in art practice as essential not only for the creators and ideologists, but also satisfies certain social and cultural needs and expectations.

The teaching process of preparation of creative project is structured according to three dominants, which correspond to the three preparatory stages:

1) mimesis - students copy existing artefacts and art sources, learn the experience gained in faceto-face communication with the master, applying it in their activities; 2) analytical - to determine the logic of construction material, its conceptualization with the help of theoretical and methodological tools for identifying the optimum balance between the concept and its practical implementation, the formation of the research programs; 3 ) reflective - selected and structured material undergoes rhetorical transformations, the final result of which is a public presentation of the project.

This model of teaching process is defined as the "rhetorical design', is introduced with the first course and completed with MA thesis. We explain the rhetorical model of the design in terms of H.-G. Gadamer's hermeneutics methodology, which explains promotion of interest in classical rhetoric, one of the three liberal arts of the classical trivium, by the fact that in the modern humanitarian science and education the notion of common sense (koine aesthesis) is updated. According to Gadamer, liberal arts can't be learnt, it can not be done, "rather, the development of this ability refers to the ability of humans to what each and every can be" [2, 206]. This type of knowledge never lost connection with the experience, prompting reflection on its practical foundations of things and processes even in the most refined types of artistic and creative activities. Common sense as a theoretical system is knowledge and training in close connection with practice, with speaking, experiences of dialogic communication as a structural principle of humanistic thinking. So, the rhetorical design involves 'speaking" ideas of the trainee with the project head and colleagues, with scientists and experts. Professional communication contributes to the development of partnerships in collaborative research, which constitute the essence of the future of art and culture project, its theoretical and practical focus on practically oriented (dual) training model, to develop the skills and competencies required for innovations.

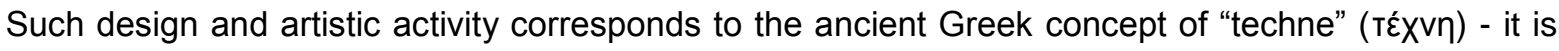
craft, art, and science at the same time [6]. A good master is determined not by technique either, nor by the ability to do something better than others, but by a thorough knowledge of the concepts, knowledge, and theoretical generalizations that he implements. That is, a fundamental requirement for the theoretical part of a MA project is to understand its fundamental principles. Thus, in the work on "Cloth Design" it is necessary to take into account the basics of design, philosophy of fashion, social and communicative principles, and resource to prognostic generalizations. The undergraduates must show his or her readiness for further research work if they want to obtain a higher education degree. This will be facilitated by the experience of creating a conceptual package of the MA project that is to work out academic papers on relevant issues, to provide scientific reports at specialized conferences, to participate in round tables. All of this is a process of conceptualizing one's own search engine experience, which MA students gain by communication in a creative workshop, in master classes, etc. The demonstration of the project will "ground" the theory, proving the legitimacy of the synthesis of art, science and technology as crafts, professions in their harmonious (ideally) combination.

Another, equally important characteristic of MA art project is its focus on both the result and selfimprovement, the development of the designer, which also resonates with ancient Greek techne - "to practice oneself", according to M. Foucault. This principle of human-like transforms arts and cultural design into a teaching planned creative experiment in which the author not only has the opportunity, but is obliged to depart from genre, style criteria, proposing his decision in accordance with the purpose and objectives, taking into account its practical relevance and relevance. This is the mechanism of calculated success, embedded in the system of training of future actors, directors, designers, musicians, which paves the way for a breakthrough - from the "one-horse" institute with two faculties to the up-to-date University, where are almost ten thousand students. This is the mechanism of calculated success that provides astate-of-the-art level of professional training at the Kiev National University of Culture and Arts. It is about forming the undergraduates ' personality, their professionalism, humanity, creative and search competences, based on our time spirit.

Students attend a MA program as mature that have a professional education and desire to improve and grow. What is the next? And then, there is a MA platform that provides training for research and development, the formation of universal, basic competencies, the ability to feel the present, the realities of modern culture, and the ability to perceive new, and improve. Here is the formation of brainpower and cultural elite of the country. Modern times are not a category of time, but a category of value; it is the present, which, according to M. Foucault, "heroizes" the present [9, 345].

How to manage to implant project thinking in the future professionals that produces creative intentions on the basis of reconstruction of cultural and historical codes of education, upbringing, education, including the experience of semiotic, rhetorical analysis, how to extrapolate it into modern education environment? We believe that there is an urgent need to start a research program on creative teaching, to develop a method of non-aggressive, non-instructive teaching approach in high and secondary schools on the basis of 